Domínios da Imagem, núm. 7, 2010, pp. 7-20.

\title{
Imagens da Infância e do Trabalho Infantil na Imprensa Manauara (1890-1920).
}

Pessoa, Alba Barbosa.

Cita:

Pessoa, Alba Barbosa (2010). Imagens da Infância e do Trabalho Infantil na Imprensa Manauara (1890-1920). Domínios da Imagem, (7), 7-20.

Dirección estable: https://www.aacademica.org/alba.barbosa.pessoa/3 ARK: https://n2t.net/ark:/13683/pwvh/dvM

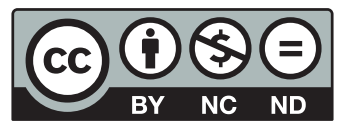

https://creativecommons.org/licenses/by-nc-nd/4.0/deed.es.

Acta Académica es un proyecto académico sin fines de lucro enmarcado en la iniciativa de acceso abierto. Acta Académica fue creado para facilitar a investigadores de todo el mundo el compartir su producción académica. Para crear un perfil gratuitamente o acceder a otros trabajos visite: https://www.aacademica.org. 


\title{
Imagens da Infância e do Trabalho Infantil na Imprensa Manauara (1890-1920)
}

\author{
Alba Barbosa Pessoa \\ Mestre em História, pesquisadora do Laboratório de História da Imprensa no Amazonas, ligado ao \\ departamento de História da Universidade Federal do Amazonas.
}

Resumo

A cidade de Manaus durante o seu primeiro processo de urbanização passou por transformações que modificaram sua arquitetura e suas relações sociais. O comércio de exportação da borracha Ihe propiciou intenso contato com as novas ideias trazidas pela modernidade, impondo mudanças não só arquitetônicas da cidade, bem como nos costumes e hábitos da população. À imprensa coube o importante papel na função de propagar esse novo modelo de sociedade que se desejava. À criança foi dedicada atenção especial nessas redefinições de papéis sociais que estava a se estabelecer. Entendendo imagem não apenas como registro fotográfico, mas também como a forma de representar algo, este artigo procura demonstrar as imagens da infância Manauara no período entre 1890 a 1920.

Palavras-chave: Infância; trabalho; imprensa.

\begin{abstract}
The first period of urbanization in Manaus city has brought change both in architecture and social relations. The business of rubber export brought an intense contact with new ideas of modernity, imposing changes not only architectural but also in customs and habits of people. The press has acted decisively as propagator of this new model of society desired. There was special attention to children in the process of redefinition of social roles that was developing and the press contributed by propagating the desired new model of childhood. Understanding "image" not only like picture register, but a representation form too. This article research images of childhood Manauara between 1890 a 1920.
\end{abstract}

Keywords: Childhood; work; press. 


\section{Imagens da Infância e do Trabalho Infantil na Imprensa Manauara (1890-1920) ${ }^{1}$}

Nas últimas décadas do século XIX, Manaus estava passando pelo seu primeiro processo de urbanização. o crescente comércio da borracha possibilitou que esta viesse a se tornar o centro exportador do látex. Frente a esse novo papel diante do mercado internacional, fazia-se necessário tornar Manaus uma cidade apta a instalar os novos empreendimentos atraídos pelo Capital. Desta forma, a camada dirigente iria colocar em prática seu projeto de construção de uma nova cidade, onde avenidas largas e prédios suntuosos a deixariam com feições semelhantes às cidades europeias. Contudo, não era somente a arquitetura que deveria ser substituída; os costumes da população, como assar peixe nas ruas, tomarbanho nos igarapés e tantos outros considerados atrasados, deveriam ser extirpados e substituídos de acordo com o modelo burguês. Portanto, o projeto de construção de uma nova cidade implicava um projeto de uma nova sociedade. Para tanto, novas posturas e novos costumes foram impostos, ocasionando um longo processo de exclusão da grande maioria da população, principalmente para os que ficaram à margem desse "período faustístico" (DIAS, 1999; PINHEIRO, 1999).

a imprensa assume importante papel na função de propagar esse novo modelo de sociedade que se desejava. As páginas dos periódicos desse período são ricas em informações, nelas podemos perceber não só a fala da população excluída, mas principalmente a fala da camada dirigente que orquestrava tal processo. as reportagens, que aparentemente apenas informavam ao leitor sobre as últimas notícias, camuflavam um discurso muitas vezes imbuído de preconceitos que, preconizados pela elite local, reverberavam em diversos setores da sociedade.

Aos jornais desse período, uns com mais veemência e outros com bem menos, atribuiu-se a tarefa de levar à população os valores da civilização. caberia a eles, a função de iluminar os caminhos do homem em direção ao progresso. Eles se afirmavam como porta-vozes do processo civilizador que se tentava implantar na cidade de Manaus, propagando a necessidade de a população adquirir novas formas de viver. $^{2}$

Esse é o caso do jornal intitulado $A$ Voz de Loriga, publicado em Manaus pela Colônia Loriguense, que afirmava ter como programa a "regeneração da moralidade, esperando um porvir moral, intelectual e material". ${ }^{3} \mathrm{De}$ forma semelhante, o periódico O Combate propagava em seu edital, intitulado "a LUZ", ser papel da Imprensa ensinar o caminho a

\footnotetext{
1 Parte de minha dissertação de Mestrado em História intitulada Infância e Trabalho: dimensões do trabalho infantil na cidade de Manaus (1890-1920). 2010. (Dissertação de Mestrado) UFaM-Manaus, 2010.

2 As práticas tradicionais da população como cozinhar, estender roupas, brincar e gritar nas ruas, tomar banho nos igarapés, entre outros costumes, passaram a ser vistos como sinônimo de atraso, sendo denunciados constantemente pelos periódicos locais. A frequência de tais denúncias revela a resistência por parte da população em adquirir os novos hábitos impostos.

3 A Voz de Loriga: Órgão da Colônia Loriguense em Manaus. Manaus, 1 de agosto de 1909. p. 1.
} 
ser trilhado pelo homem civilizado em direção ao progresso. ${ }^{4}$

No entanto, a adesão da imprensa a esse projeto não foi homogênea, não foi unívoca,

diversas folhas locais colocaram-se criticamente frente às mudanças, principalmente denunciando os limites estreitos e os comprometimentos dessa 'modernidade' manauara (PINHEIRo, 2001, p.94).

Dentre os vários jornais que tomaram para si a missão de livrar a população menos culta dos costumes primitivos e vícios degradantes, destacamos o Jornal do Commercio. Sua atuação foi emblemática na divulgação de novos valores, talvez por pertencer a uma classe conservadora e fazer parte da elite que propunha um novo modelo de cidade, tenha se empenhado de forma mais categórica numa campanha higienizadora da cidade. No ano de sua fundação, ${ }^{5} 0$ Jornal do Commercio já começa a pregar novas posturas a favor da moral, cobrando da polícia ações contra o aumento de casas de tolerância na cidade. Da mesma forma, virá a ser alvo de denúncias desse jornal a presença de inúmeros cachorros pela cidade que durante a noite, quando a população se deita para descansar das atividades diárias, tinha o sono perturbado pelo "ladrar irritante das matilhas vagabundas. É um barulho infernal, em todos os trechos da cidade, em todos os recantos da urbs [...] tudo gane, tudo uiva e ladra, num choro diabólico ensurdecedor"; 6 as buzinas persistentes dos carros que insistiam em acioná-las, mesmo sem necessidade; a limpeza do lixo que deveria ser feita durante a noite e não durante o dia, pois atraia inúmeros urubus, incomodando os moradores; a presença de vendedores nas ruas da cidade que, ao exporem suas mercadorias, atrapalham o trânsito se distanciando em muito dos povos de bons costumes $;{ }^{7}$ contra a presença de portadores de doenças contagiosas, como a lepra, que trabalhavam em alguns comércios retalhistas, ou andavam nos bondes e frequentavam os botequins junto às pessoas sãs. Neste artigo, o autor reconhece que o local existente para confinamento desses doentes não é dos mais adequados, mas que ainda assim sejam tomadas providências para que eles sejam internados, pois era constrangedor tanto para eles, portadores da doença, quanto para o resto da população. ${ }^{8}$

Enfim, esses e muitos outros temas foram alvos de campanhas por parte deste jornal, uns com menos frequência, outros quase que diariamente. Percebe-se que embora se proclamasse paladino das causas populares, defensor da moral e dos bons costumes, tais discursos mascaravam toda uma carga de tensão e preconceito existente na cidade. Seus discursos nos possibilitam entrever a exclusão dos segmentos que não se adequavam ao novo modelo de sociedade o qual a modernidade estava a exigir (PINHEIRO, 1999, p.50). Era necessário sanear a cidade da prostituição, ou pelo menos que ela não ficasse tão visível; tirar os vendedores com suas mercadorias das ruas ficando apenas as casas comerciais; não mostrar, à luz do dia, o lixo produzido pela cidade; confinar os doentes de lepra e outras doenças contagiosas. Mais que se mostrar preocupado com a saúde dos doentes ou da população sã, o jornal revelava o quanto incomodava a

\footnotetext{
4 OCombate, no1. Manaus, 25 de julho 1915. p. 1.

5 Para estudos sobre a trajetória do Jornal do Commercio consultar: ALVES, 2009; SOUZA, 2005.

Jornal do Commercio, no 4405. Manaus, 30 de julho de 1916. p. 1

Jornal do Commercio, n4464. Manaus, 29 de setembro de 1916. p. 1

Jornal do Commercio, nำ423. Manaus, 19 de agosto de 1916. p. 1.
} 
presença dessas pessoas nas ruas do centro da cidade, não sendo este um cartão de visita adequado a uma cidade que havia se tornado cosmopolita e estava a receber milhares de visitantes. Era uma paisagem que causava mais repugnância que caridade.

Sendo assim, será nessa imprensa que tentaremos captar as imagens retratadas das crianças na cidade de Manaus (cHaRtIER, 2002). ${ }^{9}$ Uma imprensa que embora se afirmasse defensora das causas populares teve papel fundamental no processo de exclusão dessa classe. Damesma formacomo na estrutura física da cidade, que estava a ser construída, havia lugares distintos para as famílias pobres e para as famílias ricas, os jornais desse período, em suas páginas, também reservavam lugares distintos para elas. Em Manaus, a exemplo de outras cidades brasileiras, a representação feita da criança terá como pilar o grupo econômico a qual esta faz parte, (PEREIRA, 2006; MOURA, 2003) $)^{10}$, retratando duas imagens distintas: a criança rica e a criança pobre.

as crianças ricas passeiam pelas primeiras páginas do jornal. São encontradas nas colunas sociais, sendo motivo de felicitações pelo seu batizado, pelo seu aniversário e outras datas festivas. A elas são dirigidos adjetivos carinhosos e todo um tratamento diferenciado, que de imediato nos faz perceber se tratar de filho (a) de algum cidadão de destaque na sociedade local. Isso pode ser ilustrado pela notícia publicada no jornal Diário de Manáos informando que "batizouse anteontem a interessante menina..., dileta filha do ilustre sr. capitão...."11 ou ainda as felicitações pelo aniversário do pequeno "William, um encanto a florir, uma formosa inteligência que se abre no lar amantíssimo do capitão..., estimado escriturário do Banco do Brasil... conta, hoje, o terceiro aniversario de seu natal". ${ }^{12}$

Esse tratamento diferenciado também pode ser percebido nas notas fúnebres, nas quais os filhos das famílias ricas também recebem tratamento distinto. A notícia vem sob o título "os mortos", sendo composta de adjetivos elogiando as qualidades do morto, bem como evidencia o pesar e a consternação causada pelo falecimento. A elas se fazia referências tais como "o enterro da inocente..." ou "a pequenita extinta..." ${ }^{13}$.

A fim de propagandear o perfil de criança que se queria para a cidade que estava sendo construída, o Jornal do Commercio passa a publicar em suas páginas domingueiras um álbum infantil destinado a divulgar fotos de crianças menores de sete anos de idade $^{14}$. Em todos os domingos, a primeira página deste jornal estampa cerca de doze a dezenove fotos de crianças nas mais diversas poses. Sentadas em cadeiras, deitadas em almofadas, em pé ao lado dos móveis pousam

\footnotetext{
9 Para além do registro fotográfico, entendemos por imagem a forma de retratar ou representar algo. E por representação, comungamos com o conceito de Chartier para quem as representações são apresentações de uma dada realidade social, não sendo neutras ou estáticas, visto atenderem interesses de grupos sociais, tendo sido, portanto, criadas a partir da percepção, da visão de mundo dos grupos que as representam. (cHaRtlER, 2002).

10 Para trabalhos abordando as representações das crianças na cidade de Florianópolis e em Pernambuco, respectivamente: PEREIRA, 2006; MOURA, 2003. Para Moura, as crianças de Pernambuco eram representadas "a partir de vários signos e normatizações dependendo da categoria social a qual pertenciam" (MoURa, 2003, p. 26).

11 Diário de Manaus. Manaus, 26 de agosto de 1892. p.1

12 Jornal do Commercio, no4000. Manaus, 15 de junho de 1915. p.1. Tal tratamento foi encontrado em todo o período pesquisado.

${ }_{13}$ Quando se tratava da morte de uma pessoa pobre, esta era noticiada sob o título de "obituário" e constava apenas do nome do morto, sua origem e a causa da morte. É frequente encontrarmos em uma mesma página de jornal os dois tipos de notas fúnebres. Tal distinção foi encontrada em todo o período pesquisado.

${ }^{14}$ Em nossa pesquisa encontramos o álbum a partir do no 3991 publicado no mês de maio de 1915 até o no 4095 de 19 de setembro de1915.
} 
graciosamente para a máquina fotográfica. Os trajes são os mais variados, desde bebês usando apenas meias e sapatinhos, até crianças usando ricos vestidos ornados com bordados, babados, laços e rendas. tais vestimentas são acompanhadas de chapéus e sapatos adequados. Os pequerruchos vestidos de marinheiros e fantasiados de palhacinhos, ricamente trajados, também se fazem presentes. A grande maioria das fotos enviadas era de crianças nascidas no estado.

Caso fosse suprimida a legenda que identifica o nome dos pais dos referidos menores, ainda assim as aparências de crianças saudáveis, nutridas e bem cuidadas evidenciariam tratar-se de filhos da elite manauara.

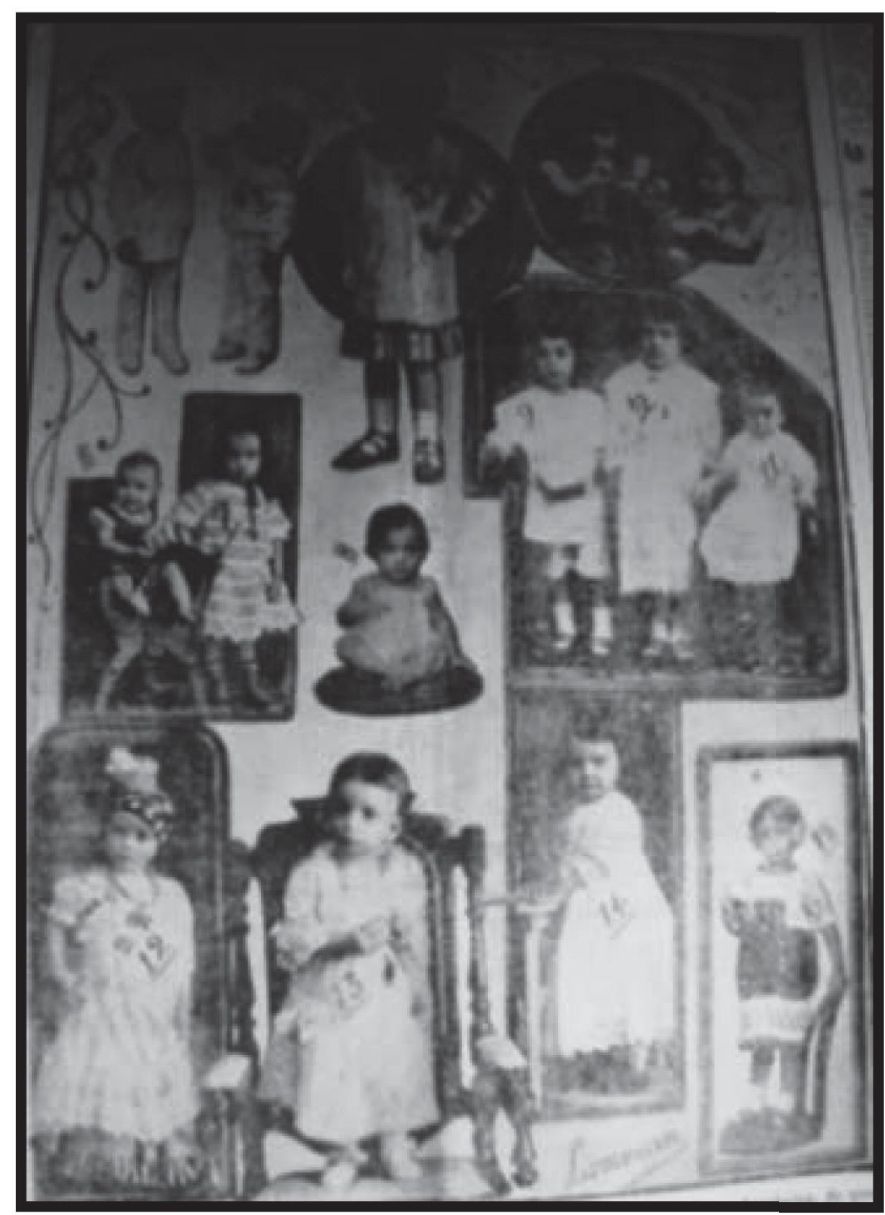

Álbum Infantil publicado no Jornal do Commercio.

Podemos inferir que estes álbuns retratavam a imagem da criança que se queria, devendo, portanto, ser propagada. "Tais crianças de bons costumes e hábitos saudáveis é que se tornariam bons cidadãos do amanhã." Entendemos que essa evidência se concretiza nas notas que antecedem o encerramento da publicação do álbum infantil, nas quais o Jornal do Commercio afirma que o referido álbum 
é um meio de se mostrar lá por fora, em outros meios, que o amazonas também, nas gerações que vão surgindo, possui perfeitas criações, cheias de todos os traços exigidos pela beleza ${ }^{15}$.

Tal observação deixa evidente que o álbum tinha como finalidade propagar a imagem da criança moderna, sem os traços da descendência indígena da região. $E$ que nesse período, uma parte da população já poderia ser apontada como moderna, dentro dos moldes que a modernidade estava a impor.

Imagens de crianças sadias, cheias de graças e encantos não eram divulgadas somente nos jornais, elas também se faziam presentes nos álbuns de fotografias da cidade bem como nas revistas de variedades ${ }^{16}$. tais álbuns, encomendados pela administração pública, tinham como finalidade atrair investimentos do capital nacional e internacional, para tanto, em alguns anos, eles apresentaram em suas páginas, além do idioma português, os idiomas francês e inglês. Além de conter o histórico da cidade e o crescimento econômico da região, suas páginas estavam repletas de imagens mostrando o quão a cidade vinha mudando de feições, com a construção de prédios luxuosos, com a pavimentação do aglomerado urbano, construção de praças e implantações de lojas comerciais que operavam com produtos importados diretamente da Europa. tais representações demonstravam que a cidade estava apta aos investimentos estrangeiros e às atrações turísticas.

Nas páginas dos referidos álbuns, podemos identificar vários segmentos sociais. alguns desses segmentos aparecem apenas como transeuntes anônimos, outros como coadjuvantes de um plano maior da fotografia. Outros segmentos, no entanto, aparecem como enfoque principal da imagem, dentro destes encontramos as crianças filhas da elite.

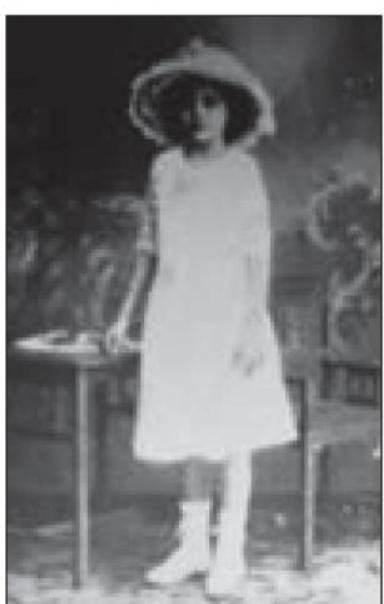

Ánnuario de Manáos (1913-1914)

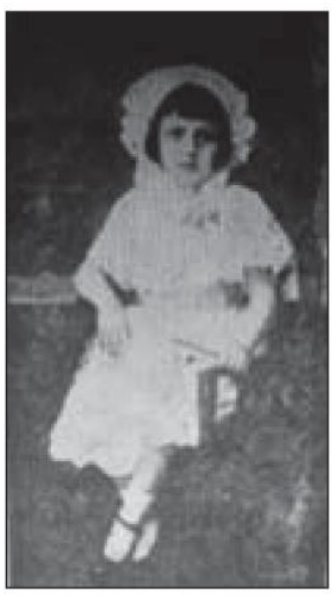

Revista Cá e Lá, no 8. (1917)

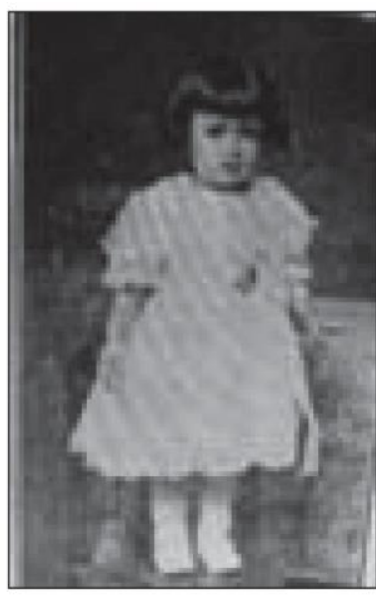

Revista Cá e Lá, no 6. (1917)

\footnotetext{
15 Jornal do Commercio, no 4055 . Manaus, 10 de agosto de 1915. p.1.

16 Para a presente pesquisa, utilizamos os seguintes álbuns: Álbum da Cidade de Manaus (1848-1948), Álbum do Amazonas (19011902), Indicador llustrado do Estado do Amazonas (1910), Álbum Municipal de Manaus (1929), Annuario de Manaus (1913-1914), Manaus 310 Anos.
} 
São crianças que portam roupas de seda, rendas, cambraias e cetins. Tais figurinos, pertencentes aos requintes da moda parisiense, demonstram que tais pequenos pertencem a famílias de destaque na sociedade local. Ainda que desconsiderássemos a mobília que compõe a foto, visto esta ser, possivelmente, produzida em um estúdio fotográfico, e as legendas que identificam estes menores, pelos seus trajes, não seria difícil inferir a que extrato social pertenciam.

Nas revistas de variedades eram retratadas comemorando aniversário, participando de concursos de robustez ou simplesmente pelo fato de serem filhos de personalidades da cidade. ${ }^{17}$ Sempre acompanhadas de tratamentos afetuosos, suas imagens desfilavam pelas páginas das revistas, distribuindo graça e beleza.

a análise de tais imagens de crianças na cidade de Manaus nos leva a acreditar que tais representações não eram feitas ao acaso, elas visavam preencher uma ausência. Assim, a divulgação de fotos de crianças limpas, saudáveis e bem cuidadas, muito provavelmente poderia ter a intenção de ocultar outro tipo de infância vivenciada em Manaus, a infância a qual estava sujeita a criança pobre. Em outras palavras, a representação da criança rica teria o papel de ocultar a imagem da criança pobre, devendo este espaço vir a ser ocupado pelas imagens das crianças mais favorecidas. Seria a ausência da criança que se queria, sendo preenchido por uma minoria de crianças que viviam em condições consideradas ideais.

Os espaços reservados pelos jornais às crianças pobres, na cidade de Manaus, difere dos espaços destinados às crianças ricas. ao contrário destas, aquelas não são encontradas em colunas sociais, em felicitações de aniversários nem em batizados.

a elas são legadas as notas policiais, as colunas de queixas e as colunas de chamada para emprego. Em todo o período pesquisado, as crianças pobres são notícias em reportagens sobre espancamentos, acidentes de trabalho, furtos e fugas, o que nos leva a afirmar que a imagem da criança pobre retratada na imprensa manauara estava relacionada ao trabalho infantil, ao vício, aos pequenos delitos, a ociosidade e vadiagem.

a vadiagem, nas últimas décadas da passagem do século XIX para o século XX, em todo o Brasil passou a ser motivo de sérias preocupações por parte do Estado. Uma intensa campanha foi deflagrada no sentido de incutir o valor do trabalho na população brasileira. Esta, saindo do contexto de um sistema escravista, via o trabalho como algo degradante e sem valor (KOWARICK, 1982, p.10). Foi necessário todo um processo coercitivo, a fim de atrair as camadas populares para o trabalho regular, para o trabalho "disciplinado". A ociosidade passou a ser vista como desvio de conduta, sendo imperativo introjetar o amor pelo trabalho. Leis e Códigos de Posturas passam a combater a vadiagem exigindo uma ocupação produtiva. O trabalho passa a ser visto como a regeneração do homem, passando a ser associado à moral e ao caráter do cidadão.

Pautado nesse novo valor de trabalho, na cidade de Manaus, o comércio da borracha, nas últimas décadas do século XIX, possibilitou o contato da elite local com

\footnotetext{
17 No caso, trabalhamos especificamente com a Revista Cá e Lá de nํ6 e nํㅇ do ano de 1917. Tal revista, destinada aos segmentos privilegiados da sociedade local, tratava de assuntos variados tais como notas sociais, humor, poemas e fatos políticos envolvendo personalidades.
} 
um modelo de vida europeu, que se impunha não só em seus traçados arquitetônicos e traçados urbanos, mas em toda uma visão de mundo. Eram os ventos da modernidade soprando sobre Manaus, que iria exigir todo um reordenamento dos seus espaços, que iria normatizar a postura de seuscidadãos, de seus costumes e suas tradições. E no bojo dessas transformações, a imprensa desempenhou papel fundamental como propagadora dos ideais do novo modelo de sociedade que se estava a aspirar. códigos de posturas serão criados na tentativa de extirpar a vadiagem, ações policiais tentam colocar tais leis em prática, porém será a imprensa que terá o papel mais eficaz nessa empreitada. É ela que irá difundir, conforme os seus interesses políticos e econômicos, projetos de intervenção social que solidificarão os valores econômicos do grupo dominante (PINHEIRO, 2001, p.17).

Assim como em outras cidades do país, a presença de crianças nas ruas de Manaus passou a ser motivo de preocupação por parte das camadas dirigentes e por parte da imprensa que vão retratá-las como vadias e ociosas e com grandes possibilidades de se tornarem delinquentes.

É uma pena ver-se algumas pobres creanças que andam por ahi pelas ruas vagabundeando, habituando-se ao vício, esquecidas do trabalho, sem um officio, sem um meio certo de subsistência.

Muitas vezes formam grupos nos logares de mais movimento da cidade e é de ver-se então o desbragamento da linguagem, o palavreado garoto, a gyria a que já estão acostumando. Um bom correctivo para esses candidatos do vicio certo que seria uma obra digna e merecedora de applausos...

avançamos mais: serão alguns criminosos de menos em dias futuro. ${ }^{18}$ o periódico retrata a imagem da criança pobre, sem ocupação e ofício como criminosos em potencial, necessitando de corretivos por parte da polícia, pois, na sociedade moderna, o trabalho passou a ser visto como regeneração de todos os males da humanidade. Não trabalhar era estar exposto a todos os vícios.

Essa preocupação dos jornais em sanear as ruas de um segmento social que teimava em não se enquadrar no modelo de sociedade que se queria, corroborava com a postura das autoridades locais. Isso pode ser observado no Código Municipal de 1893, em que ficava proibido correr, dar gritos, chamar palavras que atentassem contra a moralidade nas ruas, praças estradas de Manaus sob pena de multa ou reclusão. ${ }^{19}$ Essa postura pode ser observada no jornal Gazeta da tarde, por meio da notícia que irá comparar as crianças pobres que perambulavam pelas ruas a cães sem donos, que ficavam até altas horas da noite a fazerem barulhos com latas, chamando obscenidades e riscando com giz e carvão as portas e calçadas dos moradores. Como solução, o jornal indica o recurso à polícia. ${ }^{20}$ tal imagem também pode ser percebida no Jornal do Commercio.

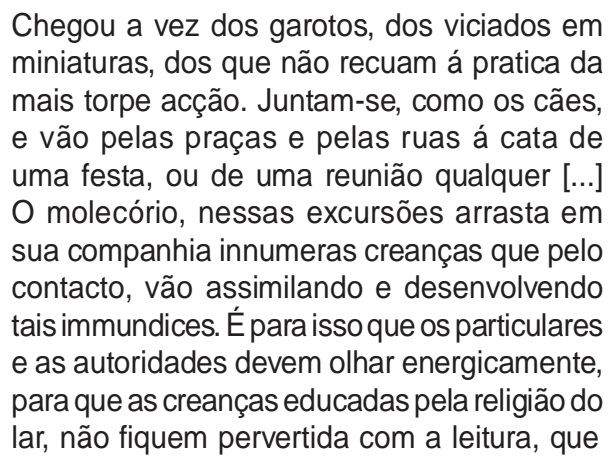

\footnotetext{
${ }_{18}$ Commercio do Amazonas, no 404. Manaus, 24 de fevereiro de 1899, p.1.

19 código Municipal de 1893. Ofensas a moral pública. Artigo 109, capítulo VII, de 23 de maio de 1893.

20 Gazeta da Tarde, № 832. Manaus, 9 de junho de 1916. p. 2.
} 
da cartilha do desrespeito, da zombaria e da immoralidade. ${ }^{21}$

A reportagem demonstra que há total intolerância por parte dos dois periódicos em relação às crianças pobres que teimam em transitar pelas ruas de Manaus. os adjetivos depreciativos que os jornais utilizam demonstram a ameaça com que eram vistas. Tal notícia não as acusa de furto ou algo semelhante, mas deixam evidente a repulsa que causam. O fato de não seguirem as normas estabelecidas, de não trabalharem, não seguirem as regras consideradas de acordo com a moral além de não estarem no domínio familiar as tornava seres execráveis, alvos da contínua preocupação em corrigir defeitos e extirpar vícios. ${ }^{22}$ Para o jornal, a criança que estivesse sob o domínio familiar poderia seguir as normas de boa conduta para com a família e sociedade. Em outras palavras, haveria a maior possibilidade de vir a tornar-se um cidadão de bem voltado para os valores do trabalho. Enquanto que as crianças vivendo a perambular pelas ruas, não iriam adquirir os preceitos da moral, estando assim sujeitas aos vícios que a rua oferecia.

Não era levado em consideração o fato de que essas crianças tinham, assim como a maior parte da população pobre, uma relação particular com a rua. a rua para eles estava para além de uma via de trânsito, sendo o lugar onde criavam laços mais sólidos na busca pela sobrevivência. O ficar na rua também pode ser visto como uma forma de estas crianças negarem regras que thes estavam sendo impostas, uma não aceitação do enquadramento social.
Essa imagem relacionando a criança com a vadiagem também foi frequente em outras cidades do país. Em Florianópolis, segundo Juliana Sardá (2005), diariamente os periódicos noticiavam com muita frequência a presença de crianças e jovens que se reuniam nas ruas (SaRDÁ, 2005, p.93). Em importante estudo sobre a vadiagem na Bahia, Walter Fraga Filho afirma que um jornal local denunciava os meninos que frequentemente estavam à porta da igreja fazendo deboches com os transeuntes (FILHo, 1989, p.114). $\mathrm{Na}$ cidade de São Paulo, as autoridades policiais também estavam preocupadas com as crianças nas ruas. Heloisa de Faria cruz aponta que, desde a virada do século XIX para o século XX, o elevado índice de crianças maltrapilhas mendigando pela cidade era motivo de reuniões entre as autoridades policiais (cRUZ, 1991, p.66). E ainda para São Paulo, a pesquisa de Gislane campos de azevedo destaca que "até mesmo o ajuntamento de crianças ou brincadeiras de rua eram tidos como perigosos" (aZEVEDo, 1995, p.62).

$\mathrm{Na}$ cidade de Manaus, destoando dos grandes jornais que quase sempre representavam as vozes do poder, os pequenos jornais como O Papagaio demonstravam um olhar diferenciado em relação às crianças como podemos observar pelo poema.

\footnotetext{
Nunca vistes pellas ruas das sonoras capitaes, enguedelhados, e aos ais, pequeninos de pés nus... as carnes transidas nuas, Nuncavistes os passarinhos, que choram longe da luz? o'Homens do mundo novo, São elles-filhos do povo. ${ }^{23}$
}

\footnotetext{
21 Jornal do Commercio, n־4415. Manaus, 10 de agosto de 1916. p. 1.

22 Jornal do Commercio, n441. Manaus, 07 de agosto de 1916, p.1 e n4419 de 15 de agosto de 1916 , p.1.

23 O Papagaio, nำ 2. Manaus, 13 de agosto de 1899. Parte da poesia sem autoria, Baladas dos Filhos do Povo.
} 
Sob esta ótica, os menores vivem a vagar pelas ruas, descalços e maltrapilhos não por vadiagem, mas sim por serem levados pela pobreza. Deixadas ao abandono pelo Estado, eles levam uma vida sofrida. Os homens com suas ideias de modernidade, portadores de projetos de cidade e sociedade, referenciados pelo poema como homens do mundo novo, não percebem que os filhos das famílias pobres estão sendo excluídos em tal processo.

Entretanto, não é apenas nos jornais que as imagens de crianças pobres podem ser encontradas. Elas também estão presentes em revistas de variedades e nos álbuns de fotografias da cidade. Diferente do observado nasimagens dos filhos das famílias mais favorecidas, a criança pobre não é o foco principal da fotografia. Ela aparece como coadjuvante ou parte do cenário que compõe a fotografia. Da mesma forma, nos álbuns da cidade, as crianças pobres não são fotografadas em estúdios, elas aparecem como transeuntes ou trabalhadores anônimos cujos rostos não eram o alvo principal das máquinas fotográficas. Tais impressos nos revelam a sua presença nos mais variados cantos da cidade. Caminhando pelas ruas da cidade a carregar doces, jornais ou outra mercadoria. Muitas vezes descalços, o que pode ter relação com o estado de pobreza em que viviam, como também, a um antigo hábito da população mais humilde. ${ }^{24}$

Seus trajes aparentam ser de material grosseiro e sem aprimoramento na sua confecção. Alguns com a perna da calça comprida rasgada, outros com camisas por dentro das calças, usando suspensórios, parecendo um pequeno adulto. também podem ser vistos ora encostados aos muros das lojas de confecções, ora pousando junto ao corpo de funcionários a frente ou dentro dos estabelecimentos comerciais; trabalhando em hotéis, gráficas ou servindo bebidas em bares e cafés, ou ainda com vassoura nas mãos. Em frente a moinhos, alfaiatarias, docerias e outros estabelecimentos. Seus tamanhos são variados, muitos com as feições de crianças entre seis a oito anos.

Taisimagensnão eramexclusivasdacidade de Manaus. No município de Itacoatiara, os menores também eram retratados nas fotografias de forma semelhante..$^{25}$

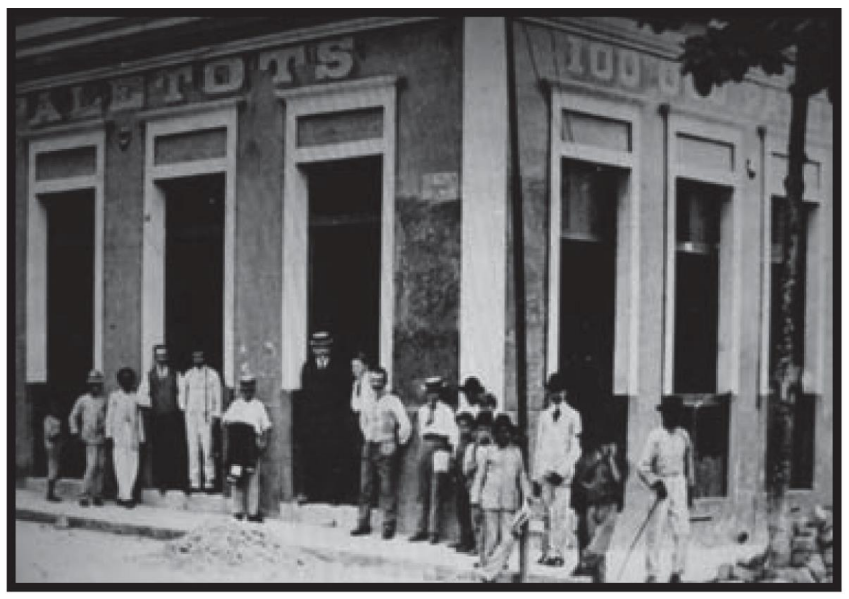

Indicador llustrado do Estado do amazonas - 1910

\footnotetext{
${ }^{24}$ andar descalço era um costume que a população pobre manteve por muito tempo, sendo que a partir dos processos de urbanização esse hábito passou a ser visto como primitivo pelos segmentos sociais que passaram a adotar o estilo de vida burguês. Hoje não é raro encontrar nos bairros mais afastados moradores que saem descalços às ruas.

25 Indicador Illustrado do Estado do Amazonas - 1910.
} 
A foto anterior tinha como finalidade divulgar o estabelecimento comercial que trabalhava com confecções de paletós. A presença de crianças na fotografia deve-se ao fato dessas provavelmente trabalharem no estabelecimento ou serem vendedores de rua. No canto esquerdo da foto, uma criança bem pequena que provavelmente aguarda para fazer algum mandado.

As imagens da criança pobre no período pesquisado não apresentam mudanças

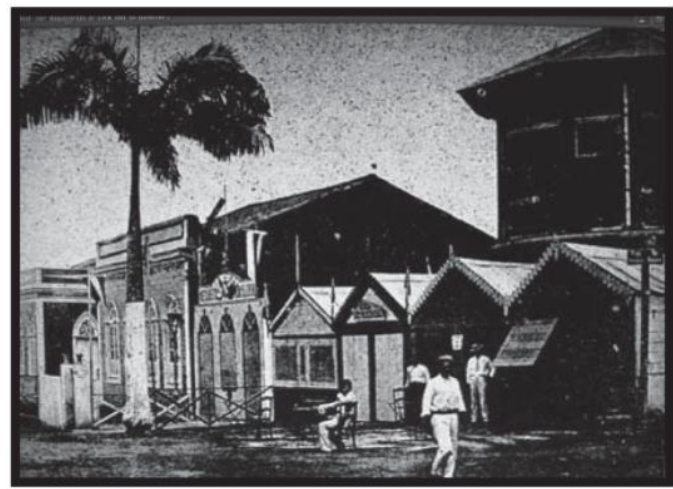

Estabelecimentos comerciais próximos a Praça dos Remédios (1893). Álbum de Manaus- 1848/1948.

como podemos observar na imagem à esquerda, a criança provavelmente aguarda sentada a chegada de novos fregueses para atender, não muito diferente da imagem ao lado, em que percebemos crianças com menos idade ainda a trabalhar no café, enquanto outras possivelmente exerçam outras atividades nas ruas. comparando as duas fotos, embora se trate de lugares diferentes, podemos perceber a transformação pela qual a estrutura física da cidade está passando, o que, contudo, parece não refletir nas condições de vida desses menores. muito significativas. Enquanto percebemos que, com o passar dos anos, a cidade vai mudando de feições com a construção de avenidas e prédios elegantes, as imagens das crianças pobres retratadas são muito semelhantes entre si, o que evidencia um descompasso entre o crescimento econômico da cidade e as condições de vida da maior parte da população, como pode ser observado nas imagens abaixo referente aos anos de 1893 e1910.

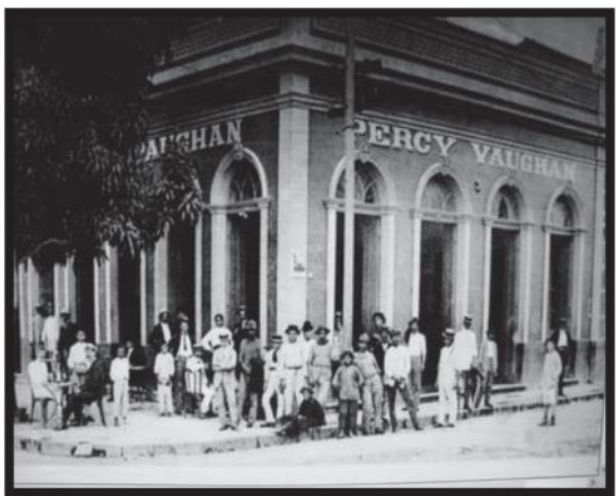

Crianças entre os adultos no trabalho avulso.

Indicador llustrado do Estado do amazonas - 1910

as crianças pobres também estão presentesnas revistas, contudo esses menores podem ser percebidos apenas nas páginas destinadas a propagandas comerciais. ${ }^{26}$ assim como nos álbuns, eles são personagens anônimos aparecendo próximos à fábrica de gelo, tabacarias e outras lojas. Geralmente estão entre adultos parecendo compor o quadro de funcionários dos referidos estabelecimentos.

Chama à atenção, a quase ausência de meninas pobres nessas imagens. Só as encontramos em ambiente familiar, em

${ }^{26}$ Revista Cáe Lánํㅛ, de 12 de maio de 1917 e nํํ, de 26 de maio de 1917. 
imagens que podem indicar estar a trabalhar em casa de famílias ricas, o que era frequente nesse período. O que, no entanto, não significa que o espaço doméstico fosse o único espaço social ocupado por elas. Os jornais desse período revelam sua presença nas fábricas e no comércio, exercendo atividades diversas tais como empacotadora de cigarros, manuseio de máquinas registradoras, atendente em botequins e outras mais (PESSoa, 2010).

Para finalizar, apresentamos a imagem que uma criança rica possivelmente fazia sobre a criança pobre. Trata-se de uma historinha publicada no jornal Pontos nos ii, em uma seção que premiava as historietas enviadas por crianças com até quatorze anos de idade. Ao anunciar a referida seção, o jornal publica uma pequena história produzida por um menino de oito anos de idade, filho de um conhecido comerciante local. Nas breves linhas, essa criança expõe a sua percepção sobre a criança pobre.

Era uma vez um menino que todo santo dia sahia com sua irmanzinha que tanto amava. Ella levava uma cestinha com flores para o mercado, e elle um balainho com passarinhos que caçava, e quando vendiam tudo iam para a casa levar o dinheiro a sua mãi, e que coitada estava, sempre doente. [...] seus dois filhinhos se esforçavam para o seu sustento e de sua mãi, á tarde sahiam cada um para o seu lado; o menino ia caçar alguns pássaros, e a menina com seu terçado capinava um roçado que havia próximo e como recompensa de seu trabalho Ihe davam umas moedinhas e depois apanhava umas flores que havia na mata e ia vender á cidade no dia seguinte, e lá iam todos os dias levar ao mercado suas mercadorias [...]..$^{27}$
Essa era a vida diária dessas duas personagens, que segundo nosso pequeno autor viveram felizes para sempre.

a imagem da criança pobre retratada nessa pequena e inocente história é de menores contribuindo para o sustento da família. Para tanto, eles utilizavam os mais variados recursos como venda em mercados e outros expedientes. Tal percepção parece ter se formado a partir de algo que parecia comum aos seus olhos, ou seja, famílias pobres que precisavam recorrer à ajuda dos filhos pequenos para garantir o sustento. crianças que passavam o dia nas ruas a fim de conseguir uns trocados para a sua sobrevivência. Enquanto esse pequeno escritor podia se dedicar à produção de história para enviar as seções infantis dos jornais, o que só seria possível se possuísse o conhecimento da leitura e da escrita, o que é muito provável, visto ser filho de comerciante de destaque, as crianças pobres passavam o dia a criar estratégias de sobrevivência a fim de garantir o sustento da família.

A análise das diversas fontes relacionadas às imagens de criança por nós, encontradas na imprensa da cidade de Manaus, leva-nos a inferir que a exclusão a que as famílias pobres estavam submetidas estava para além dos espaços geográficos, chegando a atingir todo o seu modo de viver. Sendo assim, a Manaus que estava sendo construída reservava às crianças dessas famílias um espaço diferenciado do espaço destinado aos filhos da elite. Enquanto a estes últimos estavam reservados os espaços privilegiados da cidade, às crianças pobres estavam destinados os espaços dos mundos do trabalho.

\footnotetext{
${ }_{27}$ Pontos nos ii, no5. Manaus, 11 de agosto de 1906, p.3
} 


\section{Referências}

aLVES, Hosenildo Gato. Imprensa e Poder: a propaganda varguista na imprensa amazonense (1937-1945). 2009. (Dissertação de Mestrado). UFaM, amazonas, 2009.

aZEVEDo. Gislane campos. De Sebastianas e Geovanis: o universo do menor nos processos dos juízes de órfãos da cidade de São Paulo, (18711917). 1995. (Dissertação de Mestrado). PUc-SP, São Paulo, 1995, p.63.

cHaRtIER, Roger. "o Mundo como Representação". In: À Beira da Falésia. a História entre certezas e Inquietudes. Porto alegre: Editora da Universidade/UFRGS. Tradução de Patrícia Clittoni Ramos, 2002

cRUZ, Heloisa de Faria. Trabalhadores em Serviços: dominação e resistência, São Paulo (1900-1920). São Paulo: Marco Zero, 1991, p.66.

DIAS, Ednéa Mascarenhas. Ilusão do Fausto: Manaus, 1890-1920. Manaus: Editora Valer, 1999.

FaUSto, Boris. Trabalho Urbano e Conflito Social. São Paulo: Difel, 1976.

FILHo, Walter Fraga. Meninos, Moleques e Vadios: na Bahia do século XIX. Belo Horizonte: EDUFBA, 1989.

FOUCAULT, Michel. Vigiar e Punir: história da violência nas prisões. 36.ed. Petrópolis, RJ: Vozes, 2009.
KOWARICK, Lúcio. Trabalho e Vadiagem: a Origem do Trabalho Livre no Brasil. São Paulo: Brasiliense, 1987.

MoURa, Vera Lúcia Braga de. Pequenos Aprendizes: assistência à infância desvalida em Pernambuco no século XIX. 2003. (Dissertação de Mestrado). Recife, 2003.

PEREIRa, Ivonete. Crianças e Adolescentes pobres à sombra da delinqüência e da desvalia: Florianópolis, 1900-1940. 2006. (tese de Doutorado). UFPR, curitiba, 2006.

PESSoa, alba Barbosa. Infância e Trabalho: dimensões do trabalho infantil na cidade de Manaus (1890-1920). 2010. (Dissertação de Mestrado) UFaM-Manaus, 2010. p.132-160.

PINHEIRo, Maria Luiza Ugarte. A Cidade Sobre os Ombros: trabalho e conflito no porto de Manaus (1889-1925). Manaus: EDUa, 1999.

. Folhas do Norte-Letramento eperiodismo no amazonas (1980 - 1920). 2001. (tese de Doutorado). PUc, São Paulo, 2001.

SaRDÁ, Juliana. Na Contramão da Lei: a repressão policial e os desviantes da ordem em Florianópolis nas primeiras décadas do século XX. 2005. (Dissertação de Mestrado). Florianópolis: UFSc, Florianópolis, 2005.

SoUZa, Leno José Barata. Vivência Popular na Imprensa Amazonense: Manaus da borracha (1908-1917). 2005. (Dissertação de Mestrado) PUc, São Paulo, 2005. 
